Ann. rheum. Dis. (1960), 19, 338.

\title{
INCIDENCE OF THE ANTI-NUCLEAR FACTOR IN HUMAN SERA
}

\author{
BY \\ W. R. M. ALEXANDER, JOAN M. BREMNER, AND J. J. R. DUTHIE \\ From the Rheumatic Diseases Unit, Northern General Hospital, Edinburgh
}

Miescher and Fauconnet (1954) reported that the ability of serum from patients suffering from disseminated lupus erythematosus (D.L.E.) to induce the formation of L.E. cells was abolished if the serum was previously incubated with nuclear material. Friou (1957), using the Coons' technique, showed that cells in unfixed sections of tissue exposed to serum from patients with D.L.E. and, subsequently, to fluorescein-conjugated anti-human globulin serum, exhibited nuclear fluorescence. The presence of an anti-nuclear factor (A.N.F.) in this disease has been confirmed by other workers and the subject has recently been reviewed by Holman and Kunkel (1959).

Goodman, Fahey, Malmgren, and Brecher (1959) have identified A.N.F. as a gamma globulin, separable from that associated with the formation of L.E. cells. The presence of identical or closelyrelated globulins has now been reported in other diseases, particularly in those characterized by involvement of connective tissues. The results of several investigations are summarized in Table $I$.

Using the Coons' fluorescent antibody technique, A.N.F. was detected in sixty of the 62 cases of D.L.E. tested (97 per cent.) and was also present in a proportion of cases of scleroderma, dermatomyositis and polyarteritis nodosa. The incidence of A.N.F. in rheumatoid arthritis has been variously reported as less than 10 per cent. by Friou (1958a), 16 per cent. by Holborow and Weir (1958), and 48 per cent. by Duthie, Bremner, and Alexander (1959). The series of Bardawil, Toy, Galins, and Bayles (1958) is too small to be significant, but Bardawil, Hall, and Bayles (in a communication to the American Rheumatism Association quoted by Sokoloff, Bloch, Seegmiller, Stollerman, and
Yielding, 1959) detected A.N.F. in 39 per cent. of 윽 cases of severe rheumatoid arthritis. Fessel (1959), using latex particles coated with nucleoprotein as an indicator, demonstrated A.N.F. in 23 per cent. of $\underset{\varnothing}{\Phi}$ 150 rheumatoid sera tested.

Few positive results have been obtained in diseases other than those affecting connective tissue, and the observation by Friou (1958a) and Fessel (1959) tha A.N.F. was present in a number of sera exhibiting false positive reactions for syphilis is interesting view of the speculations of Moore (1956) on the possible relationship of biologic false positive $\frac{\partial}{0}$ reactions to diseases of connective tissue. Weir (1959) reported the presence of A.N.F. in five of $\stackrel{\varnothing}{\propto}$ 38 sera from patients suffering from hepatic disease $\underset{\vec{F}}{\overrightarrow{7}}$ and in 10 per cent. of patients with disease of the $\frac{0}{3}$ thyroid gland.

A.N.F. has been demonstrated in most cases of D.L.E., but the reported incidence in rheumatoid arthritis has varied widely (Table I, opposite).

This suggests that the techniques used in the several investigations differed in sensitivity, but that A.N.F. was always present in sufficiently large amounts in D.L.E. to be detected even by the less sensitive techniques. Friou (1958b), using a semi-음 quantitative method, has already shown that $\supset$ A.N.F. is usually present in higher titre in D.L.E. than in rheumatoid arthritis.

It seemed important, in view of these results and o the current view that A.N.F. may be of pathogenic ${ }^{N}$ significance in D.L.E., to screen a large number of ${ }^{N}$ human sera for A.N.F. by a sensitive technique.

The results of a survey of 1,116 sera are presented in this report with special reference to the prevalence $\frac{\varnothing}{\Phi}$ and possible significance of A.N.F. in rheumatoid? arthritis. 
TABLE I

SUMMARY OF PREVIOUS INVESTIGATIONS

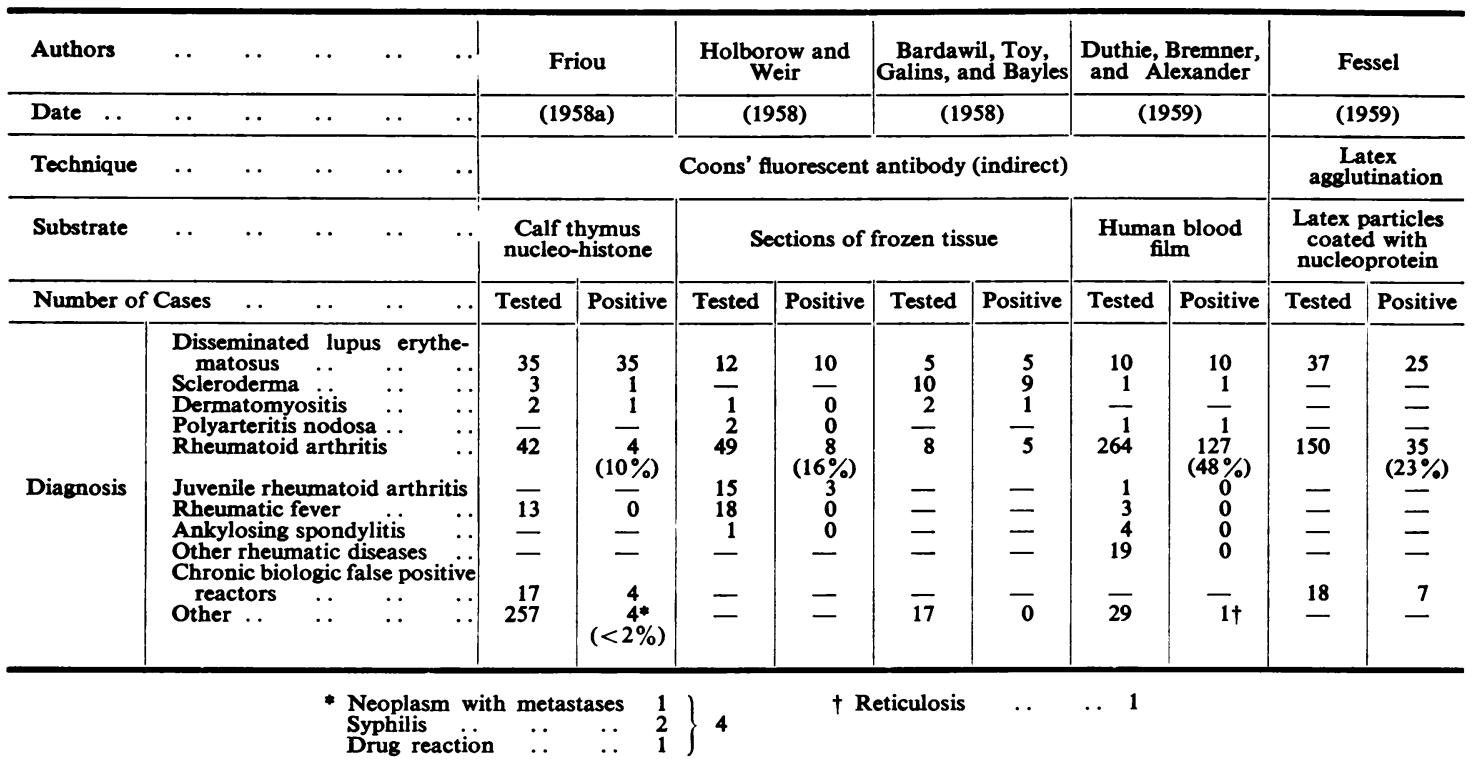

Material and Methods

Sera from 511 males and 605 females were titrated for A.N.F. Table II shows the sex and age groups of these individuals and the diagnostic categories to which they were assigned.

The small group of nineteen patients (Table III, overleaf) suffering from the classical "collagen diseases" was composed of twelve cases of D.L.E., in all of whom the L.E. cell test was positive, three cases each of scleroderma and polyarteritis nodosa, and one case of dermatomyositis. The L.E. cell test was negative in these patients.

The 183 patients suffering from rheumatoid arthritis were members of a group who had attended the rheumatic clinic for a number of years and had been studied in detail by Duthie, Thompson, Weir, and Fletcher (1955), Duthie, Brown, Knox, and Thompson (1957), and Brown

TABle II

COMPOSITION OF GROUPS BY AGE AND SEX

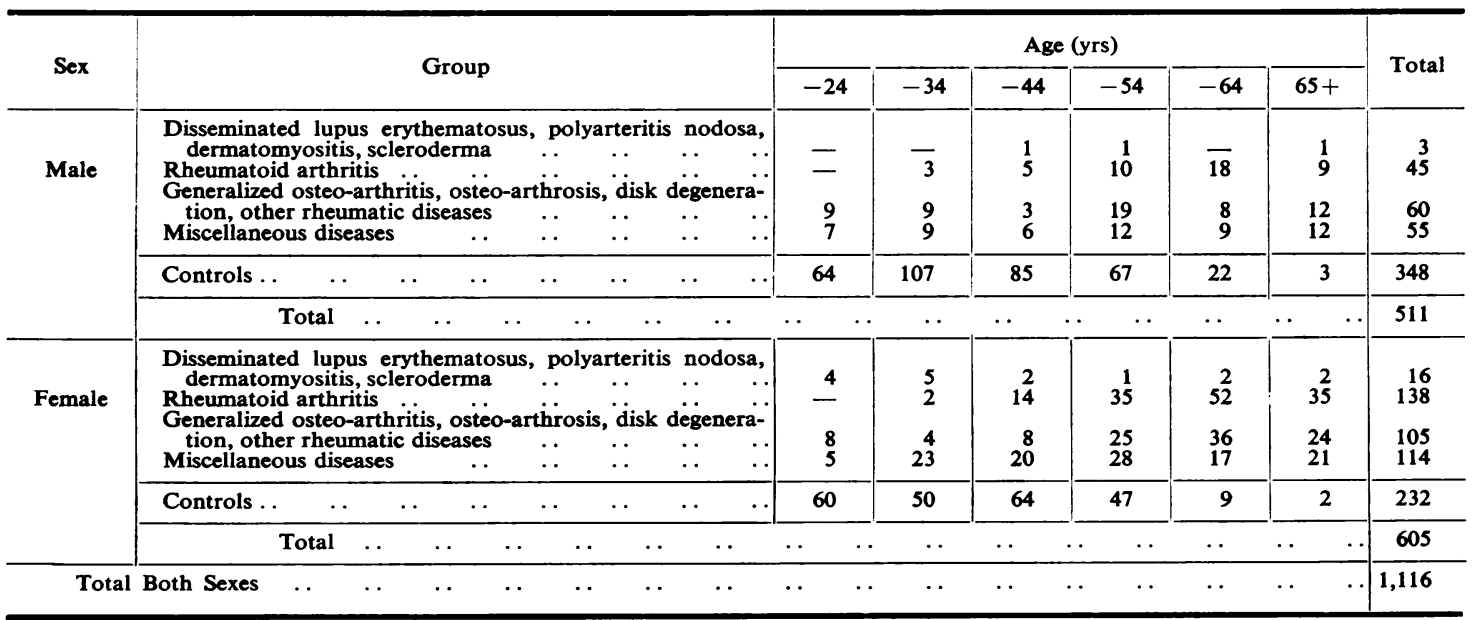


and Duthie (1958). The serological, haematological, and clinical data included in the present report were obtained at an assessment of the patients in 1959. At this time the mean age of the group was 57 years and all patients had suffered from rheumatoid arthritis for at least 8 years.

The diagnoses in the group of 165 individuals suffering from generalized osteo-arthritis, osteo-arthrosis, disk degeneration, or other rheumatic diseases are shown in Table IV (overleaf).

This group was mainly composed of patients referred to the rheumatic clinic, but included 27 persons who were seen in the course of a survey of relatives of patients with rheumatoid arthritis (Bremner, Alexander, and Duthie, 1959) and who were found to suffer from generalized osteo-arthritis, osteo-arthrosis, disk degeneration, or some minor rheumatic complaint.

The diagnoses in the 169 patients forming the group of miscellaneous diseases are shown in Table V (overleaf).

These patients had been referred to other units in the Northern Group of Hospitals with the exception of twelve who belonged to the group of relatives studied by Bremner, Alexander, and Duthie (1959). Whenever A.N.F. was detected, the diagnosis of D.L.E. or rheumatoid arthritis was definitely excluded, but mild osteoarthrosis and disk degeneration might have been present. The 23 cases of erythema nodosum formed part of a group which was the subject of a report by Truelove (1960). These patients had had articular manifestations associated with a typical rash, but only one had signs of active disease at the time when serum was obtained.

The 580 control sera were obtained from 118 healthy relatives of patients suffering from rheumatoid arthritis and 462 blood donors about whom no information other than age and sex was available.

Titration of Anti-Nuclear Factor.-The presence of A.N.F. was demonstrated by a modification of the method previously described by Alexander and Duthie (1958), and Duthie, Bremner, and Alexander (1959).

\section{REAGENTS}

Human Leucocytes.-Blood was obtained by earprick and films were spread on standard microscope slides. The films were not fixed and were allowed to dry at room temperature. Films were used on the day of preparation. Leucocytes from a single healthy donor (Group B) were used throughout the investigation, although it had been established that results were the same if leucocytes from donors of other blood groups were substituted.

Serum.-Blood was obtained from patients and controls by venepuncture. The separated serum, if not used on the day of withdrawal, was stored at $-15^{\circ} \mathrm{C}$. The titre of A.N.F. was not affected by storage under these conditions. At the time of testing, serial eight-fold dilutions of serum in phosphate saline buffer $(\mathrm{pH} 7 \cdot 0$, $0.15 \mathrm{M})$ were prepared.

Fluorescent Anti-Human Globulin Serum.-Commercial anti-human globulin* (Coombs' serum) was

\footnotetext{
* Burroughs Wellcome.
}

conjugated with fluorescein isocyanate by the method of Coons and Kaplan (1950). Excess dye was removed $\overline{3}$ from the serum by passage through a column containingo an anionic exchange resin (De-acidite* FF $(-200+400$. mesh W.R. 1-1.5) in phosphate saline buffer. The fluorescein-conjugated anti-human globulin serum was? then absorbed with sheep liver powder as described by Coons and Kaplan (1950). It was established that theo conjugated antiserum did not impart fluorescence to thes nucleus or cytoplasm of the untreated leucocytes usedo in the test.

METHOD.-Each blood film was divided into four $\overrightarrow{0}$ areas by marking the under-surface of the slide with $a_{-}$ diamond. The test serum was applied undiluted and atw $1 / 8,1 / 64$, and $1 / 512$ to the four areas, care being taken to prevent the drops of individual dilutions coalescing To minimize evaporation the preparation was placed in a covered Petri dish containing a pledget of moist $t_{-}$ cotton wool. After 30 minutes excess serum wasi washed from the slide with phosphate saline buffer $\omega_{\infty}^{\omega}$ The preparation was washed further by immersing ino phosphate saline buffer for 5 minutes and was then dried? with a cloth, care being taken to leave untouched the areas of slide exposed to the test serum. To each areap one drop of fluorescein-conjugated anti-human globulino was applied and the preparation was replaced in the Petri dish for 30 minutes at room temperature. Theop preparation was again washed in phosphate saline buffer and mounted in buffered glycerol at $\mathrm{pH} 7906$ Standard coverslips were used.

The preparations were examined in a fluoresce $\overline{\bar{c}}$ microscope modified in one respect from that described in detail by Alexander (1958). In the original microscope the specimen was mounted on a slide cut from Chance glass (OX7) which filtered all but ultraviole and violet radiation from the exciting beam. In tho present investigation it was impracticable to use such $a_{\overrightarrow{5}}$ slide in view of the large number of specimens examined.5 Standard microscope slides were therefore substituted and a filter to absorb visible radiation was placed between the source of U.V. light and the microscope. In early experiments a Wratten 18A filter, $\dagger$ which transmits U.V. radiation above $300 \mathrm{~m} \mu$ was used (Duthie, Bremner:and Alexander, 1959). It was later shown, however 3 that a Wratten 18B filter, which transmits ultraviolets light over a wider waveband, provided a more intense excitation of the specimen with a corresponding increase in sensitivity of the technique. An 18B filter was therefore used throughout the present investigation.

INTERPRETATION OF RESULTS.-The presence of greeñ fluorescence on the nuclei of polymorph leucocytes was regarded as a positive result, and the titre of thes serum was recorded as the highest dilution in which such fluorescence could be detected. Sera which werepositive at a dilution of $1 / 512$ were further diluted and retested so that an end-point could be recorded. Positive:

\footnotetext{
- Permutit Co.
}

+ Kodak Ltd 
and negative sera were titrated with each batch of tests in order to standardize the sensitivity of the technique. The reproducibility of the method was tested by duplicate titrations of 110 sera. In 95 per cent. the results of the duplicate tests agreed, but in 5 per cent. divergent results were recorded. These divergences were most frequently observed in low titre sera.

Sensitized Sheep Cell Test (S.S.C.T.).-This was performed by the method of Ball (1950) modified as described by Duthie, Brown, Knox, and Thompson (1957). A titre of $1 / 128$ was designated as the lowest positive titre in the test.

Haemoglobin (Hb) and Erythrocyte Sedimentation Rate (E.S.R.).- -Venous blood was collected in Wintrobe's anticoagulant mixture. The haemoglobin concentration was measured by the alkali haematin method of Clegg and King (1942) in a photo-electric colorimeter. Results were expressed as a percentage of $14.8 \mathrm{~g}$. $\mathrm{Hb} / 100 \mathrm{ml}$. blood.

The E.S.R. was measured in Westergren tubes. The fall in $\mathrm{mm}$. after 1 hour was recorded.

Functional Capacity.-This was assessed only in the patients suffering from rheumatoid arthritis, and was graded as follows:

I. Fit for all normal duties.

II. Moderate restriction (usual employment with modifications, light or part-time work; all housework except the heaviest; no dependency on others).

III. Marked restriction (only very light work; some degree of dependency on others).

IV. Confined to bed or chair (not capable of any work; completely dependent on others).

\section{Results}

INCIDENCE OF ANTI-NUCLEAR FACTOR

In Disseminated Lupus Erythematosus, Polyarteritis Nodosa, Scleroderma, and Dermatomyositis (Table III).-A.N.F. was detected in the serum of all patients suffering from D.L.E. and in ten of the twelve sera a titre greater than 1/64 was recorded. A.N.F. was also present in the serum of three patients suffering from polyarteritis nodosa and in that of one patient suffering from dermatomyositis. It was present in the serum of two of three patients with scleroderma. In this small series the incidence of A.N.F. was almost as high as in D.L.E., but the titre did not exceed 1/64 in any instance.

The S.S.C.T. was positive in five of the nineteen sera from patients in this group. A.N.F. was present in all five sera, but the titres were not related to the titres for sensitized sheep cells.

In Rheumatoid Arthritis.-A.N.F. was present in the serum of 65 per cent. of the 183 patients with rheumatoid arthritis. The titre was greater than 1/64 in twenty cases (11 per cent.). A detailed analysis of A.N.F. in relation to age, sex, duration of disease, haemoglobin, E.S.R., functional capacity, and the S.S.C.T. is presented in a later section of this report.

In Other Rheumatic Diseases (Table IV, overleaf). Serum was tested from 49 patients suffering from a polyarthritis conforming to the clinical and radiological pattern of generalized osteo-arthritis as described by Kellgren and Moore (1952). A.N.F. was present in eleven of the 49 sera ( 22 per cent.). The arthritis was associated with a raised E.S.R. in fourteen of the patients in this group. A.N.F. was present in the serum of four of these fourteen patients, and reached a titre of $1 / 64$ in three instances.

There was evidence of co-existing disease in five of the 49 patients, but A.N.F. was not demonstrated in their serum.

A.N.F. was present in three of twenty sera (15 per cent.) from patients suffering from secondary osteoarthrosis. Of the three patients with a positive

TABLE III

INCIDENCE OF A.N.F. IN CLASSICAL "COLLAGEN DISEASES"

\begin{tabular}{|c|c|c|c|c|c|c|c|c|c|}
\hline \multirow{3}{*}{\multicolumn{2}{|c|}{ Diagnosis }} & \multicolumn{6}{|c|}{ A.N.F. } & \multirow{3}{*}{$\begin{array}{c}\text { Total } \\
\text { No. } \\
\text { Tested }\end{array}$} & \multirow{3}{*}{ No. Positive } \\
\hline & & \multirow{2}{*}{ Absent } & \multicolumn{5}{|c|}{ Present (titre) } & & \\
\hline & & & $1 / 1$ & $1 / 8$ & $1 / 64$ & $1 / 512$ & $>1 / 512$ & & \\
\hline $\begin{array}{l}\text { Disseminated lupus eryth } \\
\text { Polyarteritis nodosa } \\
\text { Dermatomyositis . . } \\
\text { Scleroderma } \\
\end{array}$ & 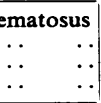 & $\bar{z}$ & E & $\frac{1}{2}$ & $\begin{array}{l}1 \\
1 \\
1 \\
1\end{array}$ & $\underline{5}$ & E & $\begin{array}{r}12 \\
3 \\
1 \\
3\end{array}$ & $\begin{array}{r}12 \\
3 \\
1 \\
2\end{array}$ \\
\hline Total No. of Cases & $\ldots$ & 1 & 0 & 4 & 4 & 5 & 5 & 19 & 18 (95 per cent.) \\
\hline
\end{tabular}


TABLE IV

INCIDENCE OF A.N.F. IN GENERALIZED OSTEO-ARTHRITIS, OSTEO-ARTHROSIS, DISK DEGENERATION, AND OTHER RHEUMATIC DISEASES

\begin{tabular}{|c|c|c|c|c|c|c|c|c|c|}
\hline \multirow{3}{*}{ Diagnosis } & \multicolumn{6}{|c|}{ A.N.F. } & \multirow{3}{*}{$\begin{array}{c}\text { Total } \\
\text { No. } \\
\text { Tested }\end{array}$} & \multirow{2}{*}{\multicolumn{2}{|c|}{ No. Positive }} \\
\hline & \multirow{2}{*}{ Absent } & \multicolumn{5}{|c|}{ Present (titre) } & & & \\
\hline & & $1 / 1$ & $1 / 8$ & $1 / 64$ & $1 / 512$ & $>1 / 512$ & & Total & Per cent \\
\hline 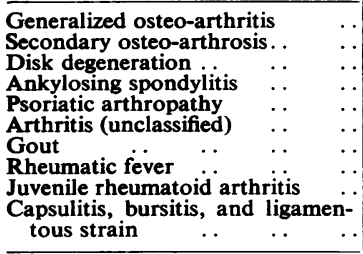 & $\begin{array}{r}38 \\
17 \\
28 \\
12 \\
6 \\
1 \\
9 \\
8 \\
7 \\
16 \\
\end{array}$ & $\begin{array}{r}5 \\
2 \\
4 \\
2 \\
1 \\
1 \\
- \\
- \\
-\end{array}$ & $\begin{array}{l}2 \\
= \\
= \\
= \\
=\end{array}$ & $\begin{array}{l}4 \\
1 \\
= \\
= \\
= \\
- \\
-\end{array}$ & $\begin{array}{l}= \\
= \\
= \\
= \\
=\end{array}$ & $\begin{array}{l}= \\
= \\
= \\
= \\
=\end{array}$ & $\begin{array}{r}49 \\
20 \\
33 \\
14 \\
7 \\
2 \\
9 \\
8 \\
7 \\
7 \\
16\end{array}$ & $\begin{array}{r}11 \\
3 \\
5 \\
2 \\
1 \\
1 \\
= \\
- \\
-\end{array}$ & $\begin{array}{l}22 \\
15 \\
15 \\
= \\
= \\
= \\
-\end{array}$ \\
\hline Total No. of Cases ... & 142 & 15 & 2 & 6 & 0 & 0 & 165 & 23 & - \\
\hline
\end{tabular}

test, however, one suffered concomitantly from congestive cardiac failure and another had swelling of one proximal interphalangeal joint but no other signs compatible with the diagnosis of rheumatoid arthritis or generalized osteo-arthritis. The titre of A.N.F. in the sera from these two patients was $1 / 64$ and $1 / 1$ respectively.

A.N.F. was demonstrated in five of 33 sera (15 per cent.) from patients in whom symptoms were attributed to degeneration of cervical or lumbar intervertebral disks. One patient, in whose serum A.N.F. was detected at a titre of $1 / 1$, suffered also from a chronic infection of the upper urinary tract. In a further patient, about whom clinical data was incomplete, A.N.F. was present at a titre of 1/64.

A.N.F. was present in undiluted serum in two of fourteen patients with ankylosing spondylitis, in one of seven patients with psoriatic arthropathy, and in one patient suffering from a destructive arthritis of the hip joints of undetermined origin. A.N.F. was not demonstrated in gout, rheumatic fever, juvenile rheumatoid arthritis, or in patients presenting with non-articular lesions.

The S.S.C.T. was negative in all cases of generalized osteo-arthritis and secondary osteo-arthrosis, but was positive in one patient with disk degeneration. There was no clinical or radiological evidence of rheumatoid arthritis in this patient and A.N.F. was not present in her serum.

The S.S.C.T. was positive in two cases of juvenile rheumatoid arthritis, in one case of gout, and in one case of psoriatic arthropathy. A.N.F. was not detected in these four sera.

A proportion of the patients included within these diagnostic categories were relatives of patients suffering from rheumatoid arthritis. The incidence of A.N.F. was not affected by exclusion of the relatives from the analysis.

In Miscellaneous Diseases.-The incidence an titre of A.N.F. in relation to diagnosis in the group of 169 patients suffering from miscellaneous diseases is shown in Table V (opposite). A.N.F. was demon? strated in 17 per cent. of sera from this group, bugib only two instances (1 per cent.) was the titre gresep than $1 / 8$. The number of patients in any single diagnostic category is too small for analysis.

The S.S.C.T. was positive in six of the 169 patients in this group (4 per cent.). There was no clinical evidence of rheumatoid disease in thes patients and A.N.F. was not present in their serum?

In Controls. - The incidence and titre of A.N.F in relation to age and sex in the control group is shown in Table VI (opposite). The incidence of A.N.F. did not differ between the sexes. It was detected in sera from 4 per cent. of males and females. In females A.N.F. was present in a higher proportion of sera from individuals belonging to the older age groups, but because of the small numbers in these groups the possible significance of this trend could not be established. In the 24 sera of both sexes in which A.N.F. was detected, the titre was greate than $1 / 8$ in only one instance, and there was ne. evidence that titre was related to age.

The S.S.C.T. was performed in 553 of the $58 \%$ controls, and a positive test was recorded in eight of them (1 per cent.). Co-existence of A.N.F. and rheumatoid agglutinating factor occurred in onlए one serum, obtained from a woman of 61. She ha甲 previously complained of arthralgia, but no clinica\$ or radiological evidence of arthritis was present at the time of examination. 
TABLE $\mathbf{V}$

\section{INCIDENCE OF A.N.F. IN MISCELLANEOUS DISEASES}

\begin{tabular}{|c|c|c|c|c|c|c|c|c|c|c|c|}
\hline \multirow{3}{*}{\multicolumn{2}{|c|}{ Diagnosis }} & & & \multicolumn{6}{|c|}{ A.N.F. } & \multirow{3}{*}{$\begin{array}{l}\text { Total } \\
\text { No. } \\
\text { Tested }\end{array}$} & \multirow{3}{*}{$\begin{array}{c}\text { Total } \\
\text { Positive }\end{array}$} \\
\hline & & & & \multirow{2}{*}{ Absent } & \multicolumn{5}{|c|}{ Present (titre) } & & \\
\hline & & & & & $1 / 1$ & $1 / 8$ & $1 / 64$ & $1 / 512$ & $>1 / 512$ & & \\
\hline $\begin{array}{l}\text { Pulmonary tuberculosis .. } \\
\text { Hamman-Rich syndrome } \\
\text { Chronic bronchitis } \\
\text { Other respiratory diseases }\end{array}$ & $\begin{array}{l}\cdots \\
\cdots \\
\cdots \\
\end{array}$ & $\begin{array}{l}\cdots \\
\cdots \\
\cdots \\
\end{array}$ & $\begin{array}{l}\cdots \\
\cdots \\
\cdots \\
\end{array}$ & $\frac{4}{6}$ & $\begin{array}{r}3 \\
1 \\
- \\
\end{array}$ & $\bar{z}$ & E & E & E & $\begin{array}{l}7 \\
1 \\
6 \\
6 \\
\end{array}$ & $\begin{array}{r}3 \\
1 \\
- \\
\end{array}$ \\
\hline $\begin{array}{l}\text { Congestive cardiac failure } \\
\text { Myocardial infarct } \\
\text { Cerebro-vascular lesion } \ldots \\
\text { Hypertension } \quad . .\end{array}$ & $\begin{array}{l}\cdots \\
\cdots \\
\cdots\end{array}$ & $\begin{array}{l}\cdots \\
\cdots \\
\cdots\end{array}$ & $\begin{array}{l}\cdots \\
\cdots \\
\cdots \\
\cdots\end{array}$ & $\begin{array}{l}2 \\
2 \\
3 \\
1\end{array}$ & $\frac{1}{-}$ & - & $\frac{1}{-}$ & $\bar{z}$ & E & $\begin{array}{l}5 \\
2 \\
3 \\
1\end{array}$ & $\frac{3}{-}$ \\
\hline $\begin{array}{l}\text { Peptic ulcer } \\
\text { Hepatitis and cirrhosis } \ldots \\
\text { Cholecystitis and cholelithiasis } \\
\text { Crohn's disease .. } \\
\text { Other gastro-intestinal diseases }\end{array}$ & $\cdots$ & $\begin{array}{l}\cdots \\
\cdots \\
\cdots \\
\cdots\end{array}$ & $\begin{array}{l}\cdots \\
\cdots \\
\cdots \\
\cdots\end{array}$ & $\begin{array}{l}7 \\
7 \\
5 \\
3 \\
2 \\
8\end{array}$ & $\begin{array}{l}2 \\
1 \\
- \\
-\end{array}$ & $\begin{array}{l}-1 \\
-\end{array}$ & $\begin{array}{l}- \\
\bar{E} \\
-\end{array}$ & $\begin{array}{l}- \\
- \\
-\end{array}$ & $\begin{array}{l}\bar{z} \\
\bar{E}\end{array}$ & $\begin{array}{l}9 \\
7 \\
3 \\
2 \\
8\end{array}$ & $\begin{array}{r}2 \\
2 \\
- \\
-\end{array}$ \\
\hline $\begin{array}{ll}\text { Hashimoto's disease } & \ldots \\
\text { Hyperparathyroidism } & \ldots \\
\text { Diabetes mellitus } & \ldots \\
\text { Myxoedema } & \text { Other endocrine diseases } \\
\end{array}$ & $\begin{array}{l}\cdots \\
\cdots \\
\cdots \\
\cdots\end{array}$ & $\begin{array}{l}\cdots \\
\cdots \\
\cdots \\
\cdots\end{array}$ & $\begin{array}{l}\cdots \\
\cdots \\
\cdots \\
\cdots\end{array}$ & $\begin{array}{l}1 \\
2 \\
3 \\
2 \\
2\end{array}$ & $\begin{array}{l}- \\
- \\
-\end{array}$ & $\frac{1}{-}$ & $\bar{E}$ & $\bar{E} \bar{z}$ & $\begin{array}{c}E \\
E \\
-\end{array}$ & $\begin{array}{l}2 \\
2 \\
3 \\
2 \\
2\end{array}$ & $\frac{1}{-}$ \\
\hline $\begin{array}{ll}\text { Disseminated sclerosis } & \ldots \\
\text { Epilepsy } \ldots & \ldots \\
\text { Viral encephalitis } & \ldots \\
\text { Other neurological diseases }\end{array}$ & $\begin{array}{l}\cdots \\
\cdots \\
\cdots\end{array}$ & $\begin{array}{l}\cdots \\
\cdots \\
\cdots \\
\end{array}$ & $\begin{array}{l}\cdots \\
\cdots \\
\cdots \\
\cdots\end{array}$ & $\begin{array}{l}7 \\
4 \\
2 \\
7 \\
7\end{array}$ & 二 & 二 & E & E & $\begin{array}{l}- \\
-\end{array}$ & $\begin{array}{l}7 \\
4 \\
2 \\
7\end{array}$ & $\begin{array}{l}- \\
- \\
-\end{array}$ \\
\hline $\begin{array}{l}\text { Erythema nodosum } \\
\text { Discoid lupus erythematosus }\end{array}$ & $\begin{array}{l}\cdots \\
\cdots\end{array}$ & $\cdots$ & $\cdots$ & $\begin{array}{r}18 \\
1 \\
\end{array}$ & 2 & $\underline{3}$ & 二 & - & - & $\begin{array}{r}23 \\
1\end{array}$ & 5 \\
\hline $\begin{array}{l}\text { Carcinoma of breast } \\
\text { Other malignant disease }\end{array}$ & $\begin{array}{l}\cdots \\
\cdots\end{array}$ & $\cdots$ & $\cdots$ & 5 & $\overline{2}^{*}$ & 1 & - & - & - & $\begin{array}{l}6 \\
7\end{array}$ & $\begin{array}{l}1 \\
2\end{array}$ \\
\hline $\begin{array}{l}\text { Toxaemia of pregnancy } \\
\text { Other miscellaneous diseases }\end{array}$ & $\cdots$ & $\cdots$ & $\cdots$ & $\begin{array}{r}4 \\
29 \\
\end{array}$ & $\begin{array}{l}1 \\
4+\end{array}$ & $\overline{2}+$ & - & $\overline{1 \S}$ & - & $\begin{array}{r}5 \\
36\end{array}$ & 1 \\
\hline Total $\ldots$ & $\ldots$ & $\ldots$ & $\ldots$ & 141 & 17 & 9 & 1 & 1 & - & 169 & $\begin{array}{c}28 \\
(17 \%)\end{array}$ \\
\hline
\end{tabular}

- Metastatic carcinoid tumour ${ }_{2}+$ Cyst in breast

TABLE VI

RELATIONSHIP OF AGE AND SEX TO TITRE OF A.N.F. IN CONTROLS

\begin{tabular}{|c|c|c|c|c|c|c|c|c|c|}
\hline \multirow{3}{*}{ Sex } & \multirow{3}{*}{$\begin{array}{c}\text { Age } \\
\text { Group } \\
\text { (yrs) }\end{array}$} & & \multicolumn{4}{|c|}{ A.N.F. } & \multirow{3}{*}{$\begin{array}{c}\text { Total } \\
\text { No. } \\
\text { Tested }\end{array}$} & \multirow{2}{*}{\multicolumn{2}{|c|}{ No. Positive }} \\
\hline & & & \multirow{2}{*}{ Absent } & \multicolumn{3}{|c|}{ Present (titre) } & & & \\
\hline & & & & $1 / 1$ & $1 / 8$ & $1 / 64$ & & lotal & Per cent. \\
\hline \multirow[t]{2}{*}{ Male } & $\begin{array}{c}0-24 \\
25-34 \\
35-44 \\
45-54 \\
55+\end{array}$ & & $\begin{array}{r}62 \\
102 \\
81 \\
64 \\
25\end{array}$ & $\begin{array}{r}2 \\
3 \\
4 \\
- \\
\end{array}$ & $\frac{-2}{3}$ & $\begin{array}{l}z \\
z\end{array}$ & $\begin{array}{r}64 \\
107 \\
85 \\
67 \\
25\end{array}$ & $\begin{array}{l}2 \\
5 \\
4 \\
3 \\
0\end{array}$ & $\begin{array}{l}3 \\
5 \\
5 \\
5 \\
\end{array}$ \\
\hline & Total & . & 334 & 9 & 5 & $\mathbf{0}$ & 348 & 14 & 4 \\
\hline \multirow[t]{2}{*}{ Female } & $\begin{array}{c}0-24 \\
25-34 \\
35-44 \\
45-54 \\
55+\end{array}$ & & $\begin{array}{r}59 \\
49 \\
61 \\
45 \\
8\end{array}$ & $\begin{array}{l}1 \\
1 \\
2 \\
1 \\
3\end{array}$ & $\frac{-}{1}$ & $\begin{array}{l}- \\
- \\
-\end{array}$ & $\begin{array}{l}60 \\
50 \\
64 \\
47 \\
11\end{array}$ & $\begin{array}{l}1 \\
1 \\
3 \\
2 \\
3\end{array}$ & $\begin{array}{r}2 \\
2 \\
5 \\
4 \\
25\end{array}$ \\
\hline & Total & $\cdots$ & 222 & 8 & 1 & 1 & 232 & 10 & 4 \\
\hline \multicolumn{2}{|c|}{ Total Both Sexes } & $\cdots$ & 556 & 17 & 6 & 1 & 580 & 24 & 4 \\
\hline
\end{tabular}


ANTI-NUClear FaCtor in Rheumatoid Arthritis

Age and Sex (Table VII).-A.N.F. was present in the serum of 60 per cent. of males and 67 per cent. of females, and in both sexes the incidence was higher in the older age groups. This trend was more pronounced in males, but a true difference in pattern between the sexes could not be established because of the small numbers in the younger age groups.

The distribution of titres differed between the sexes. In females the peak incidence of positive tests occurred at a titre of $1 / 8$ and not, as in males, in undiluted serum. No relationship between titre and age was apparent in females, but in males titres greater than $1 / 64$ were recorded only in patients over the age of 55 .

Duration of Disease (Table VIII).-The lowest $\frac{\text { D }}{\text {. }}$

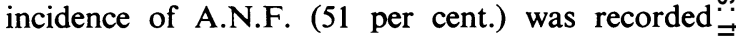
in sera from patients who had suffered from rheumatoid arthritis for 8 to 10 years, the shortesto duration available for analysis in this study. The흐 incidence was directly related to duration of disease $\frac{\bar{\sigma}}{\bar{D}}$ and A.N.F. was detected in 83 per cent. of patients $\overparen{Q}$ in whom the duration of disease was 20 years or more. There was, however, no close association ${ }^{\text {es }}$ of high titres with long duration of disease.

Concentration of Haemoglobin (Table IX).- $\overrightarrow{\vec{\omega}}$ A.N.F. was present in the serum of all patients in

TABLE VII

RELATIONSHIP OF AGE AND SEX TO PRESENCE AND TITRE OF A.N.F.

\begin{tabular}{|c|c|c|c|c|c|c|c|c|c|c|}
\hline \multirow{3}{*}{ Sex } & \multirow{3}{*}{$\underset{\text { Group }}{\text { Agrs) }}$} & \multicolumn{6}{|c|}{ A.N.F. } & \multirow{3}{*}{$\begin{array}{c}\text { Total } \\
\text { No. } \\
\text { Tested }\end{array}$} & \multicolumn{2}{|c|}{ No. Positive } \\
\hline & & \multirow{2}{*}{ Absent } & \multicolumn{5}{|c|}{ Present (titre) } & & Total & Per cent \\
\hline & & & $1 / 1$ & $1 / 8$ & $1 / 64$ & $1 / 512$ & $>1 / 512$ & & 1010 & 20. \\
\hline \multirow[t]{2}{*}{ Male } & $\begin{array}{c}0-34 \\
35-54 \\
55+\end{array}$ & $\begin{array}{r}2 \\
10 \\
6 \\
\end{array}$ & $\begin{array}{l}1 \\
2 \\
9 \\
\end{array}$ & $\begin{array}{l}-1 \\
6\end{array}$ & $\begin{array}{r}-2 \\
3\end{array}$ & $\frac{-}{2}$ & $\overline{1}$ & $\begin{array}{r}3 \\
15 \\
27 \\
\end{array}$ & $\begin{array}{r}1 \\
5 \\
21 \\
\end{array}$ & $\begin{array}{l}33 \\
33 \\
77 \\
\end{array}$ \\
\hline & Total & 18 & 12 & 7 & 5 & 2 & 1 & 45 & 27 & 60 \\
\hline \multirow[t]{2}{*}{ Female } & $\begin{array}{c}0-34 \\
35-54 \\
55+ \\
\end{array}$ & $\begin{array}{r}2 \\
17 \\
27 \\
\end{array}$ & $\begin{array}{r}7 \\
15 \\
\end{array}$ & $\begin{array}{l}\overline{10} \\
18 \\
\end{array}$ & $\begin{array}{l}\overline{10} \\
15 \\
\end{array}$ & $\begin{array}{r}-3 \\
9 \\
\end{array}$ & $\begin{array}{r}-2 \\
3\end{array}$ & $\begin{array}{r}2 \\
49 \\
87 \\
\end{array}$ & $\begin{array}{l}\overline{32} \\
60\end{array}$ & $\begin{array}{l}\overline{65} \text { 음 } \\
69 \text { 은 }\end{array}$ \\
\hline & Total & 46 & 22 & 28 & 25 & 12 & 5 & 138 & 92 & 67 ำ \\
\hline \multicolumn{2}{|c|}{ Total Both Sexes } & 64 & 34 & 35 & 30 & 14 & 6 & 183 & 119 & $65 \stackrel{+}{\rightleftharpoons}$ \\
\hline
\end{tabular}

TABLE VIII

RELATIONSHIP OF DURATION OF DISEASE TO PRESENCE AND TITRE OF A.N.F.

\begin{tabular}{|c|c|c|c|c|c|c|c|c|}
\hline \multirow{3}{*}{$\begin{array}{c}\text { Duration of } \\
\begin{array}{c}\text { Disease } \\
(y r s)\end{array}\end{array}$} & \multirow{3}{*}{ Absent } & \multicolumn{4}{|c|}{ A.N.F. } & \multirow{3}{*}{$\begin{array}{c}\text { Total } \\
\text { No. } \\
\text { Tested }\end{array}$} & \multirow{2}{*}{\multicolumn{2}{|c|}{ No. Positive }} \\
\hline & & \multicolumn{4}{|c|}{ Present (titre) } & & & \\
\hline & & $1 / 1$ & $1 / 8$ & $1 / 64$ & $1 / 512$ or Over & & Total & Per cent. \\
\hline $\begin{array}{l}8-10 \\
10-15 \\
15-20 \\
\text { Over } 20\end{array}$ & $\begin{array}{r}23 \\
27 \\
8 \\
6\end{array}$ & $\begin{array}{r}8 \\
12 \\
9 \\
5\end{array}$ & $\begin{array}{r}5 \\
13 \\
6 \\
11\end{array}$ & $\begin{array}{r}6 \\
12 \\
4 \\
8\end{array}$ & $\begin{array}{l}5 \\
5 \\
4 \\
6\end{array}$ & $\begin{array}{l}47 \\
69 \\
31 \\
36\end{array}$ & $\begin{array}{l}24 \\
42 \\
23 \\
30\end{array}$ & $\begin{array}{l}51 \\
61 \\
74 \\
83\end{array}$ \\
\hline Total & 64 & 34 & 35 & 30 & 20 & 183 & 119 & 65 \\
\hline
\end{tabular}

TABLE IX

RELATIONSHIP OF HAEMOGLOBIN CONCENTRATION TO PRESENCE AND TITRE OF A.N.F.

\begin{tabular}{|c|c|c|c|c|c|c|c|c|}
\hline \multirow{3}{*}{$\begin{array}{l}\text { Haemoglobin } \\
(\% \text { of } 14.8 \text { g.) }\end{array}$} & \multirow{3}{*}{ Absent } & \multicolumn{4}{|c|}{ A.N.F. } & \multirow{3}{*}{$\begin{array}{c}\text { Total } \\
\text { No. } \\
\text { Tested }\end{array}$} & \multirow{2}{*}{\multicolumn{2}{|c|}{ No. Positive }} \\
\hline & & \multicolumn{4}{|c|}{ Present (titre) } & & & \\
\hline & & $1 / 1$ & $1 / 8$ & $1 / 64$ & $1 / 512$ or Over & & Total & Per cent. \\
\hline $\begin{array}{l}\text { Over } 90 \\
80-89 \\
70-79 \\
\text { Under } 70\end{array}$ & $\begin{array}{r}31 \\
24 \\
9 \\
-\end{array}$ & $\begin{array}{r}12 \\
12 \\
7 \\
3\end{array}$ & $\begin{array}{r}12 \\
16 \\
4 \\
3\end{array}$ & $\begin{array}{r}15 \\
8 \\
6 \\
1\end{array}$ & $\begin{array}{l}6 \\
5 \\
5 \\
4\end{array}$ & $\begin{array}{l}76 \\
65 \\
31 \\
11\end{array}$ & $\begin{array}{l}45 \\
41 \\
22 \\
11\end{array}$ & $\begin{array}{r}60 \\
62 \\
71 \\
100\end{array}$ \\
\hline Total & 64 & 34 & 35 & 30 & 20 & 183 & 119 & 65 \\
\hline
\end{tabular}


whom the haemoglobin concentration was less than 70 per cent., and a titre of $1 / 512$ or higher was recorded in four of these patients (36 per cent.). The incidence of A.N.F. was lowest (60 per cent.) in patients with a haemoglobin of 90 per cent. or more and the titre was $1 / 512$ or more in only six of 76 cases ( 8 per cent.).

Erythrocyte Sedimentation Rate (Table X).A.N.F. was present in the serum of 80 per cent. of the forty patients in whom the E.S.R. was $60 \mathrm{~mm}$. $/ \mathrm{hr}$ or greater, and in ten cases ( 25 per cent.) a titre of $1 / 512$ or more was recorded. In the 44 patients with an E.S.R. of $19 \mathrm{~mm}$./hr or less, A.N.F. was present in 48 per cent. The titre was $1 / 512$ or more in only three of these patients ( 7 per cent.).

Functional Capacity (Table XI).--Sera from all patients confined to bed or chair (Grade IV) contained A.N.F. The incidence decreased among patients in the higher grades of functional capacity and A.N.F. was demonstrated in only 39 per cent. of patients fit for all normal activities (Grade I). No close relationship of titre of A.N.F. to the grade of functional capacity was found, the distribution of high titres of A.N.F. being similar in all four grades.
Sensitized Sheep Cell Test (Table XII).-The presence of A.N.F. was associated with a positive S.S.C.T. in 47 per cent. of males and 42 per cent. of females. Both tests were negative in 27 per cent. and 19 per cent. of males and females respectively. In 13 per cent. of males and 14 per cent. of females the sheep cell test was positive in the absence of A.N.F. A negative S.S.C.T. was associated with the presence of A.N.F. in the serum of 25 per cent. of females but in only 13 per cent. of males.

TABLE XII

RELATIONSHIP OF THE SENSITIZED SHEEP CELL TEST TO THE PRESENCE OF A.N.F., BY SEX

\begin{tabular}{|c|c|c|c|c|c|}
\hline \multirow{3}{*}{$\begin{array}{c}\text { Sensitized } \\
\text { Sheep Cell } \\
\text { Test }\end{array}$} & \multirow{3}{*}{$\begin{array}{l}\text { Anti- } \\
\text { nuclear } \\
\text { Factor }\end{array}$} & \multicolumn{4}{|c|}{ Sex } \\
\hline & & \multicolumn{2}{|c|}{ Male } & \multicolumn{2}{|c|}{ Female } \\
\hline & & No. & Per cent. & No. & Per cent. \\
\hline Positive & Present & 21 & 47 & 58 & 42 \\
\hline Positive & Absent & 6 & 13 & 20 & 14 \\
\hline Negative & Present & 6 & 13 & 34 & 25 \\
\hline Negative & Absent & 12 & 27 & 26 & 19 \\
\hline Total & $\cdots$ & 45 & & 138 & \\
\hline
\end{tabular}

TABle X

RELATIONSHIP OF ERYTHROCYTE SEDIMENTATION RATE TO PRESENCE AND TITRE OF A.N.F.

\begin{tabular}{|c|c|c|c|c|c|c|c|c|}
\hline \multirow{3}{*}{$\begin{array}{c}\text { Erythrocyte } \\
\text { sedimentation } \\
\text { Rate } \\
\text { (mm./1 hr) }\end{array}$} & \multirow{3}{*}{ Absent } & \multicolumn{4}{|c|}{ A.N.F. } & \multirow{3}{*}{$\begin{array}{l}\text { Total } \\
\text { No. } \\
\text { Tested }\end{array}$} & \multirow{2}{*}{\multicolumn{2}{|c|}{ No. Positive }} \\
\hline & & \multicolumn{4}{|c|}{ Present (titre) } & & & \\
\hline & & $1 / 1$ & $1 / 8$ & $1 / 64$ & $1 / 512$ or Over & & Total & Per cent. \\
\hline $\begin{array}{l}0-19 \\
20-39 \\
40-59 \\
\text { Over } 60\end{array}$ & $\begin{array}{r}23 \\
24 \\
9 \\
8\end{array}$ & $\begin{array}{r}6 \\
6 \\
16 \\
6\end{array}$ & $\begin{array}{r}4 \\
17 \\
6 \\
8\end{array}$ & $\begin{array}{l}8 \\
8 \\
6 \\
8\end{array}$ & $\begin{array}{r}3 \\
2 \\
5 \\
10\end{array}$ & $\begin{array}{l}44 \\
57 \\
42 \\
40\end{array}$ & $\begin{array}{l}21 \\
33 \\
33 \\
32\end{array}$ & $\begin{array}{l}48 \\
58 \\
78 \\
80\end{array}$ \\
\hline Total & 64 & 34 & 35 & 30 & 20 & 183 & 119 & 65 \\
\hline
\end{tabular}

TABLE XI

RELATIONSHIP OF FUNCTIONAL CAPACITY TO PRESENCE AND TITRE OF A.N.F.

\begin{tabular}{|c|c|c|c|c|c|c|c|c|}
\hline \multirow{3}{*}{$\begin{array}{c}\text { Grade of } \\
\text { Functional } \\
\text { Capacity }\end{array}$} & \multicolumn{5}{|c|}{ A.N.F. } & \multirow{3}{*}{$\begin{array}{c}\text { Total } \\
\text { No. } \\
\text { Tested }\end{array}$} & \multirow{2}{*}{\multicolumn{2}{|c|}{ No. Positive }} \\
\hline & \multirow{2}{*}{ Absent } & \multicolumn{4}{|c|}{ Present (titre) } & & & \\
\hline & & $1 / 1$ & $1 / 8$ & $1 / 64$ & $1 / 512$ or Over & & Total & Per cent. \\
\hline III & $\begin{array}{l}25 \\
28 \\
11 \\
-\end{array}$ & $\begin{array}{r}3 \\
17 \\
8 \\
6\end{array}$ & $\begin{array}{r}4 \\
19 \\
7 \\
5\end{array}$ & $\begin{array}{r}5 \\
12 \\
10 \\
3\end{array}$ & $\begin{array}{l}4 \\
9 \\
5 \\
2\end{array}$ & $\begin{array}{l}41 \\
85 \\
41 \\
16\end{array}$ & $\begin{array}{l}16 \\
57 \\
30 \\
16\end{array}$ & $\begin{array}{r}39 \\
67 \\
73 \\
100\end{array}$ \\
\hline Total & 64 & 34 & 35 & 30 & 20 & 183 & 119 & 65 \\
\hline
\end{tabular}




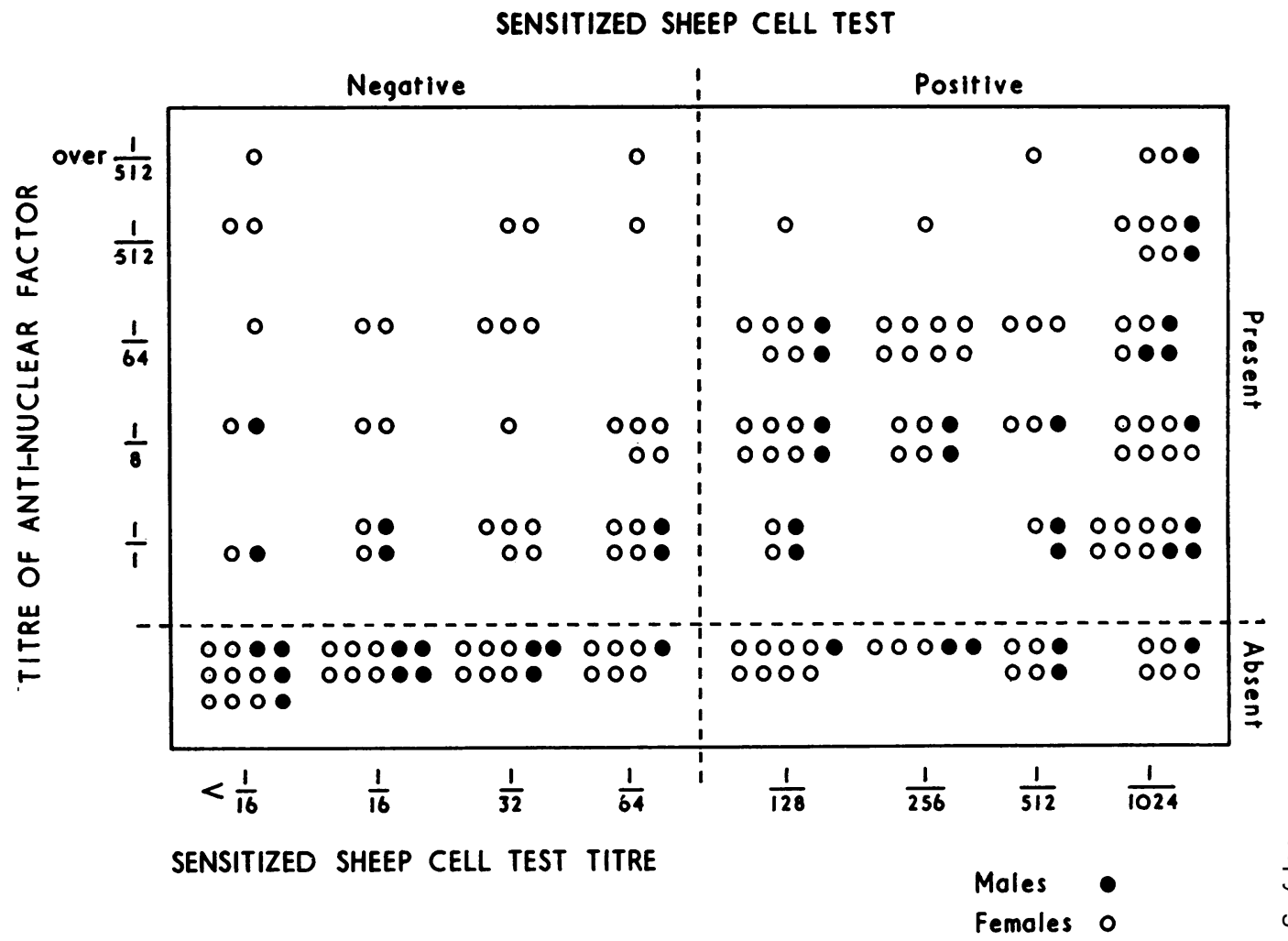

Figure.-Distribution of titres for sensitized sheep cell test and anti-nuclear factor in individual sera, by sex.

Titres of A.N.F. and rheumatoid agglutinating factor in individual patients are shown in the Figure. In the females no relationship between titres in the two tests was apparent, but in the males a titre of A.N.F. greater than $1 / 1$ associated with a negative sheep cell test was recorded in only one instance.

\section{Relationship of Anti-nuclear Factor and Sensitized Sheep Cell Test to Haemoglobin Concentration, Erythrocyte Sedimentation Rate, Functional Capacity, and Duration of Disease}

In view of the probable influence of the S.S.C.T. on prognosis (Duthie, Brown, Knox, and Thompson, 1957) and the present finding of an association of A.N.F. with some of the manifestations of active rheumatoid disease, the status of patients, grouped according to the results of both serological tests, have been compared (Table XIII, opposite).

Irrespective of the result of the S.S.C.T., a haemoglobin of less than 70 per cent. was not recorded in patients with a negative test for A.N.F. The haemoglobin was above 90 per cent. in 58 per cent. of patients in whom both tests were negative, but exceeded 90 per cent. in only 35 per cent. of patients in whom a negative test for A.N.F. was associated with a positive S.S.C.T.
47 per cent. of patients in whom both tests we negative had a normal E.S.R. compared with 19, 23, ane 15 per cent. in the other groups. E.S.R.s of $60 \mathrm{~mm}$.// or more were most frequently recorded in patients wit a positive test for A.N.F., the highest percentage (32 peE cent.) being recorded when the S.S.C.T. was also positive.

A similar trend was noted in respect of functiona capacity. Where both tests were negative, 53 per cen5 of patients were in Grade I and none was in Grade IE No patient with a negative test for A.N.F. and a positive. S.S.C.T. was in Grade IV, but only 19 per cent. were in Grade I. When both tests were positive only 9 per cent of patients were in Grade I and 14 per cent. were io Grade IV.

The duration of disease was 8-10 years in 42 per cent? of patients in whom both tests were negative, and on 8 per cent. of such patients had had the disease far 20 years or more. Where, however, both tests were positive, the disease was of short duration in only 16 peg cent. of patients, and exceeded 20 years in 27 per cent. N

From this data, and in view of the increased incidence of A.N.F. in patients with long-standing disease, $t$ seemed possible that low haemoglobin levels, rais E.S.R., and marked impairment of function might te more closely related to duration of disease than to the presence of serological abnormalities. This possibility 
TABLE XIII

RELATIONSHIP OF A.N.F. AND S.S.C.T. TO HAEMOGLOBIN CONCENTRATION, ERYTHROCYTE SEDIMENTATION RATE, FUNCTIONAL CAPACITY, AND DURATION OF DISEASE

\begin{tabular}{|c|c|c|c|c|c|c|c|c|c|c|c|c|c|c|c|}
\hline \multicolumn{2}{|c|}{ Test } & \multirow{2}{*}{$\begin{array}{c}\text { No. } \\
\text { of } \\
\text { Patients }\end{array}$} & \multicolumn{3}{|c|}{$\begin{array}{c}\text { Haemoglobin } \\
\text { (per cent.) }\end{array}$} & \multicolumn{3}{|c|}{$\begin{array}{c}\text { Erythrocyte } \\
\text { Sedimentation Rate } \\
\text { (mm./1 hr) }\end{array}$} & \multicolumn{3}{|c|}{$\begin{array}{l}\text { Functional } \\
\text { Capacity } \\
\text { (Grade) }\end{array}$} & \multicolumn{4}{|c|}{$\begin{array}{c}\text { Duration of } \\
\text { Disease } \\
\text { (yrs) }\end{array}$} \\
\hline A.N.F. & S.S.C.T. & & 90 & $70-89$ & $<70$ & $0-19$ & $20-59$ & $60+$ & I & II and & IV & $8-10$ & $10-15$ & $15-20$ & $20+$ \\
\hline- & - & 38 & $58 \%$ & $42 \%$ & - & $47 \%$ & $24 \%$ & $13 \%$ & $53 \%$ & $47 \%$ & - & $42 \%$ & $34 \%$ & $16 \%$ & $8 \%$ \\
\hline- & + & 26 & $35 \%$ & $65 \%$ & - & $19 \%$ & $57 \%$ & $12 \%$ & $19 \%$ & $81 \%$ & - & $27 \%$ & $54 \%$ & $7 \%$ & $12 \%$ \\
\hline+ & - & 40 & $43 \%$ & $42 \%$ & $15 \%$ & $23 \%$ & $33 \%$ & $16 \%$ & $23 \%$ & $65 \%$ & $12 \%$ & $28 \%$ & $28 \%$ & $22 \%$ & $22 \%$ \\
\hline+ & + & 79 & $35 \%$ & $58 \%$ & $7 \%$ & $15 \%$ & $25 \%$ & $32 \%$ & $9 \%$ & $77 \%$ & $14 \%$ & $16 \%$ & $39 \%$ & $18 \%$ & $27 \%$ \\
\hline Total & . & 183 & & & & & & & & & & & & & \\
\hline
\end{tabular}

was examined by further analysis of the serological groups subdivided in respect of duration of disease (Table XIV). The numbers in the individual categories were generally small, but are expressed in percentages to simplify comparison between groups.

The relationships between the serological findings and haemoglobin, E.S.R., and functional capacity were of the same pattern as that seen in Table XIII, and were not solely determined by the duration of disease.

\section{Discussion}

The results of this investigation suggest that A.N.F. is not specifically associated with the classical "collagen diseases" and rheumatoid arthritis, although as observed by Friou (1958a) it is present most frequently in these diseases and the highest titres occur in cases of D.L.E.

Previous workers have been mainly concerned

TABLE XIV

RELATIONSHIP OF A.N.F., S.S.C.T., AND DURATION OF DISEASE TO HAEMOGLOBIN CONCENTRATION, ERYTHROCYTE SEDIMENTATION RATE, AND FUNCTIONAL CAPACITY

\begin{tabular}{|c|c|c|c|c|c|c|c|c|c|c|c|c|}
\hline \multirow{2}{*}{$\begin{array}{c}\text { Duration of } \\
\text { Disease } \\
\text { (yrs) }\end{array}$} & \multicolumn{2}{|c|}{ Test } & \multirow{2}{*}{$\begin{array}{c}\text { No. } \\
\text { of } \\
\text { Patients }\end{array}$} & \multicolumn{3}{|c|}{$\begin{array}{c}\text { Haemoglobin } \\
\text { (per cent.) }\end{array}$} & \multicolumn{3}{|c|}{$\begin{array}{l}\text { Erythrocyte Sedimentation } \\
\text { Rate }(\mathrm{mm} . / 1 \mathrm{hr})\end{array}$} & \multicolumn{3}{|c|}{$\begin{array}{l}\text { Functional Capacity } \\
\text { (Grade) }\end{array}$} \\
\hline & A.N.F. & S.S.C.T. & & $90+$ & $70-89$ & $<70$ & $0-19$ & $20-59$ & $60+$ & I & II and & IV \\
\hline \multirow{5}{*}{$8-10$} & - & - & 16 & $75 \%$ & $25 \%$ & - & $58 \%$ & $36 \%$ & $6 \%$ & $75 \%$ & $25 \%$ & - \\
\hline & - & + & 7 & $43 \%$ & $57 \%$ & - & $15 \%$ & $85 \%$ & - & $30 \%$ & $70 \%$ & - \\
\hline & + & - & 11 & $63 \%$ & $28 \%$ & $9 \%$ & $18 \%$ & $64 \%$ & $18 \%$ & $45 \%$ & $45 \%$ & $10 \%$ \\
\hline & + & + & 13 & $23 \%$ & $69 \%$ & $8 \%$ & $15 \%$ & $62 \%$ & $23 \%$ & $23 \%$ & $62 \%$ & $15 \%$ \\
\hline & Total & . & 47 & & & & & & & & & \\
\hline \multirow{5}{*}{$10-15$} & - & - & 13 & $46 \%$ & $54 \%$ & - & $40 \%$ & $45 \%$ & $15 \%$ & $23 \%$ & $77 \%$ & - \\
\hline & - & + & 14 & $21 \%$ & $79 \%$ & - & $21 \%$ & $65 \%$ & $14 \%$ & $14 \%$ & $86 \%$ & - \\
\hline & + & - & 11 & $28 \%$ & $63 \%$ & $9 \%$ & $28 \%$ & $63 \%$ & $9 \%$ & $28 \%$ & $44 \%$ & $28 \%$ \\
\hline & + & + & 31 & $33 \%$ & $60 \%$ & $7 \%$ & $12 \%$ & $52 \%$ & $36 \%$ & $12 \%$ & $74 \%$ & $14 \%$ \\
\hline & Total & $\ldots$ & 69 & & & & & & & & & \\
\hline \multirow{5}{*}{ Over 15} & - & - & 9 & $44 \%$ & $56 \%$ & - & $44 \%$ & $34 \%$ & $22 \%$ & $56 \%$ & $44 \%$ & - \\
\hline & - & + & 5 & $60 \%$ & $40 \%$ & - & $20 \%$ & $60 \%$ & $20 \%$ & $20 \%$ & $80 \%$ & - \\
\hline & + & - & 18 & $39 \%$ & $39 \%$ & $24 \%$ & $24 \%$ & $52 \%$ & $24 \%$ & $6 \%$ & $88 \%$ & $6 \%$ \\
\hline & + & + & 35 & $43 \%$ & $51 \%$ & $6 \%$ & $18 \%$ & $52 \%$ & $30 \%$ & - & $88 \%$ & $12 \%$ \\
\hline & Total & .. & 67 & & & & & & & & & \\
\hline Total $\ldots$ & .. & .. & 183 & & & & & & & & & \\
\hline
\end{tabular}


with A.N.F. in relation to this group of diseases, and little information about the incidence in other disorders is available. Friou (1958a) detected A.N.F. in less than 2 per cent. of sera from patients suffering from miscellaneous diseases. In a comparable group in the present study, A.N.F. was present in 17 per cent. of sera, and was also demonstrated in 4 per cent. of sera from apparently healthy individuals. The discrepancy between Friou's results and those reported here is likely to be due to differences in the sensitivity of the techniques used, as a proportionate difference in incidence in rheumatoid arthritis is observed. If this explanation is correct, and if more sensitive techniques can be devised, it seems possible that A.N.F. may eventually be shown to be a normal component of human serum which is increased in some diseases, amongst which D.L.E. and the other members of the "collagen" group, including rheumatoid arthritis, are most prominent.

In view of the small numbers in any single diagnostic category, the incidence of A.N.F. in individual diseases outwith this group cannot be established. No common factor was apparent in the 17 per cent. of patients whose serum contained A.N.F., but it is interesting, in view of the report of Weir (1959), that in several instances impairment of hepatic function may have been present. The incidence of A.N.F. in secondary osteo-arthrosis and in disk degeneration approached that recorded in the miscellaneous group of diseases. It should be noted, however, that in a proportion of the cases of osteo-arthrosis and of disk degeneration where positive tests were obtained, the patients were suffering from coincident disease and it was not possible to establish that the presence of A.N.F. was related to their skeletal disorder.

In generalized osteo-arthritis, A.N.F. was detected in 22 per cent. of patients in none of whom was there evidence of other disease. This observation, together with the high incidence of generalized osteo-arthritis among females and the distinct familial predisposition, suggests that this disease may be a diffuse disorder of connective tissue, more closely related to rheumatoid arthritis than to osteoarthrosis of the secondary type.

A study of the relationship of the presence of A.N.F. to some of the features of rheumatoid arthritis has been reported by Duthie and others (1959). The incidence of A.N.F. was shown to be higher in females ( 51 per cent.) than in males (43 per cent.). No association of age or duration of disease with the presence of A.N.F. was demonstrated in females, but in males the incidence of A.N.F. was lowest ( 28 per cent.) in patients below the age of 45 , and was 30 per cent. in patients in whom the disease was of less than 10 years' duration. 3 These observations agree with the results of the present investigation within the limitations imposed: by the small numbers in the younger age groupsos? and the absence of patients in whom the durationo of disease was less than 8 years. Duthie and otherso (1959) showed that A.N.F. occurred most frequently $\frac{\overline{\bar{c}}}{\overline{6}}$ in the presence of anaemia, raised E.S.R., and low functional capacity. This relationship of A.N.F. D to signs of systemic disease has been confirmed in the present study, but no quantitative correlation. between the titre of A.N.F. and the degree of anaemia, E.S.R., or grade of functional capacity has been demonstrated.

In the earlier study, A.N.F. was present in 55 per $^{2}$ cent. of patients in whom the S.S.C.T. was positive, but in only 29 per cent. of patients with a negative S.S.C.T. The corresponding figures in the current $\omega_{\infty}^{\omega}$ investigation were 75 per cent. and 51 per cent.o respectively, the higher overall incidence beingaccounted for by the use of a more sensitive technique.

The probable prognostic significance of the $\stackrel{\mathscr{N}}{3}$ S.S.C.T. has been discussed by Duthie and others (1957), who showed that a consistently positive test was associated with a more serious prognosis giso assessed by functional capacity. The results Duthie and others (1959) suggested that the preseree of A.N.F. might also indicate a poor prognosis and it was postulated that, whereas A.N.F. was related to the systemic manifestations of disease, the rheumatoid agglutinating factor was more commonly® present when inflammatory changes in the joints $\vec{F}$ were prominent. The results of the present study 3 confirm that both A.N.F. and rheumatoid factor may be of prognostic significance and that A.N.F.0. was more closely associated both with signs of active disease and with impaired functional capacity. $\stackrel{0}{\circ}$ A.N.F. was present in the serum of all patients in $\frac{3}{3}$ whom the $\mathrm{Hb}$ concentration was less than 70 percent. and in that of all those who were in the lowesto grade of functional capacity. The influence of the S.S.C.T. on these indices was less obvious, but, in음 general, a positive test, irrespective of the presence $>$ or absence of A.N.F., was associated with lowerㅡㅡㄹ. clinical status. Patients in whom both tests weren negative generally fared better in all respects than their fellows. Although the incidence of A.N.F. N was greater in patients with prolonged disease, $N$ the relationship to clinical status was maintained independently of duration of disease.

The almost universal occurrence of A.N.F. in the classical "collagen diseases" and its association with $\stackrel{\text { ? }}{+}$ signs of systemic disturbance in rheumatoid arthritis $[0$ 
might suggest that the factor is closely linked with diseases in which diffuse inflammatory changes in connective tissue are prominent. A.N.F. has, however, been demonstrated in a number of sera from healthy individuals and in patients suffering from diseases such as osteo-arthrosis and disk degeneration in which there was no obvious evidence of inflammatory lesions.

It is possible that the A.N.F. demonstrated in D.L.E. may differ qualitatively from that present in rheumatoid arthritis and in other sera. It has been emphasized by Holman and Kunkel (1959) that, with techniques similar to those used in the present study, the homogeneity of A.N.F. cannot be established. Deicher, Holman, and Kunkel (1959) have shown that the serum in D.L.E. may contain several globulins with an affinity for tissue nuclei. A similar heterogeneity probably exists in other sera. It remains true, however, that these factors, although distinguishable one from another by special techniques, have the common property of combining with nuclear material and may be produced in response to similar stimuli. The demonstration of A.N.F., using the term in a generic sense, in a wide variety of human sera, suggests that the occurrence of the appropriate stimulus is not limited to D.L.E. or other "collagen diseases".

The stimulus to the production of A.N.F. remains unknown. The factor possesses the property of an antibody to nuclear material, but it has not been established that its production is due either to a derangement of the normal immune mechanism or to the presence of nuclear material degraded or altered to the extent that it is treated as an antigen by the cells normally responsible for synthesis of antibody. Degradation or alteration of nuclear material may follow dissolution of tissue, whether this be due to disease or to senescence of cells, and may provide the stimulus for production of A.N.F. This hypothesis is consistent with the concept of A.N.F. as a normal component of human serum, but it does not adequately explain the occurrence of large amounts of A.N.F. in the serum of patients suffering from D.L.E. and the high incidence of the factor in other "collagen diseases". Even if it should be established that A.N.F. is not of causal importance, the final explanation of its prevalence in these diseases may contribute to the understanding of their aetiology.

\section{Summary}

(1) A sensitive method for the detection and titration of anti-nuclear factor (A.N.F.) in human serum is described.

(2) The results in 1,116 sera are reported and compared with those obtained in previous investigations.

(3) Anti-nuclear factor was detected in the serum of all patients with disseminated lupus erythematosus. It was also present in three cases of polyarteritis nodosa, one case of dermatomyositis, and in two of three cases of scleroderma.

(4) Anti-nuclear factor was present in the serum of 65 per cent. of 183 patients with rheumatoid arthritis, 22 per cent. of 49 cases of generalized osteo-arthritis, 15 per cent. of twenty cases of secondary osteo-arthrosis, 15 per cent. of 33 cases of disk degeneration, 6 per cent. of 63 patients with other rheumatic conditions, 17 per cent. of 169 patients suffering from a variety of other diseases, and 4 per cent. of 580 apparently healthy individuals.

(5) In rheumatoid arthritis the incidence of antinuclear factor was highest among patients with signs of active disease (as indicated by the presence of anaemia and a rapid erythrocyte sedimentation rate) and among those with serious impairment of functional capacity. Severe disease was most common in patients in whom the presence of antinuclear factor was associated with a positive sensitized sheep cell test. Patients in whom both tests were negative had fared better in all respects than the remainder of the group.

(6) The possible significance of these results is discussed.

We are grateful to Dr. R. A. Cumming, Director, Blood Transfusion Service, Edinburgh Royal Infirmary, for supplying normal sera. We also wish to thank our colleagues in the Edinburgh Northern Group of Hospitals for supplying sera and clinical data about their patients.

During the period when this work was done, the Rheumatic Unit was in receipt of grants from the Nuffield Foundation, the Medical Research Council, the Empire Rheumatism Council, and Boots Pure Drug Company Limited.

\section{REFERENCES}

Alexander, W. R. M. (1958). Immunology, 1, 217.

Alexand Duthie, J. J. R. (1958). Brit. med. J., 2, 1565.

Ball, J. (1950). Lancet, 2, 520.

Bardawil, W. A., Toy, B. L., Galins, N., and Bayles, T. B. (1958). Amer. J. Path., 34, 607.

Bremner, J. M., Alexander, W. R. M., and Duthie, J. J. R. (1959). Ann. rheum. Dis., 18, 279.

Brown, P. E., and Duthie, J. J. R. (1958). Ibid., 17, 359

Clewg, J. W., and King, E. J. (1942). Brit. med. J., 2, 329.

Coons, A. H., and Kaplan, M. H. (1950). J. exp. Med., 91, 1.

Coons, A. H., and Kaplan, M. H. (1950). J.exp. Meed, 91, (1959) Arthr. and Rheum., 2, 364.

Duthie, J. J. R., Bremner, J. M., and Alexander, W. R. M. (1959) Communication to the Fourth European Rheumatological Congress, Istanbul.

Brown, P. E., Knox, J. D. E., and Thompson, M. (1957). Ann. rheum. Dis., 16, 411.

Thompson, M., Weir, M. M., and Fletcher, W. B. (1955). Ibid., 14, 133 .

Fessel, W.' J. (1959). Ibid., 18, 255.

Friou, G. J. (1957). Communication to Ninth International Congress on Rheumatic Diseases, Toronto. 
Friou, G. J. (1958a), Yale J. Biol. Med, 31, 40

(1958b). Ann. intern. Med., 49, 866.

Goodman, H. C., Fahey, J. L., Malmgren, R. A., and Brecher, G. (1959). Lancet, 2, 382.

Holborow, E. J., and Weir, D. M. (1958). Ann. rheum. Dis., 17, 122. Holman, H. R., and Kunkel, H. (1959). Bull. rheum. Dis., 10, 197. Kellgren, J. H., and Moore, R. (1952). Brit. med. J., 1, 181.

Miescher, P., and Fauconnet, M. (1954). Experientia (Basel), $10,252$.

Moore, J. E. (1956). Bull. rheum. Dis., 6, 109

Sokoloff, L., Bloch, K. J., Seegmiller, J. E., Stollerman, G. H., and Yielding, K. L. (1959). Ibid., 10, 193.

Truelove, L. H. (1960). Ann. rheum. Dis., 19, 174.

Weir, D. M. (1959). 23rd Annual Report of the Empire Rheumatism Council, p. 42.

\section{Fréquence du facteur antinucléaire dans le sérum humain \\ RÉSUMÉ}

(1) On décrit un procédé sensible pour dépister et titrer le facteur antinucléaire (A.N.F.) dans le sérum humain.

(2) On présente les résultats sur 1,116 sérums et on les compare avec ceux obtenus au cours des travaux antérieurs.

(3) On a décélé le facteur antinucléaire dans le sérum de tous les malades atteints de lupus érythémateux disséminé. Il était aussi présent dans trois cas de périartérite noueuse, un cas de dermatomyosite et en deux sur trois cas de sclérodermie.

(4) Le facteur antinucléaire était présent dans le sérum de $65 \%$ des malades atteints d'arthrite rhumatismale, $22 \%$ des 49 cas d'ostéoarthrite généralisée, $15 \%$ des 20 cas d'ostéoarthrite secondaire, $15 \%$ des 33 cas de dégénérescence discale, $6 \%$ des 63 cas d'autres affections rhumatismales, $17 \%$ des 169 sujets atteints d'autres maladies et de $4 \%$ des 580 sujets apparemment sains.

(5) Dans l'arthrite rhumatismale la fréquence du facteur antinucléaire était plus grande chez des sujets accusant des signes d'évolution morbide (indiquée par la présence d'anémie et une vitesse élevée de sédimentation érythrocytaire) et chez ceux dont la capacité fonctionnelle était gravement affectée. La maladie était le plus souvent sévère quand la présence du facteur antinucléaire s'associait à une agglutination positive des globules de mouton sensibilisés. Les malades chez qui les deux réactions étaient négatives allaient mieux de tous les points de vue que les autres dans le groupe.

(6) On discute l'importance possible des ces résultats.

\section{Incidencia del factor antinuclear en el suero humano \\ SUMARIO}

(1) Se describe un método sensible de detección y ڤ્ఝ titulación del factor antinuclear (A.N.F.) en el suero humano.

(2) Se presentan los resultados en 1,116 sueros y se $\vec{A}$ comparan con los obtenidos en investigaciones previas.

(3) Se detectó factor antinuclear en el suero de todos los enfermos con lupus eritematoso diseminado. Estaba presente también en tres casos de periarteritis nodosa, un caso de dermatomiositis y en dos de tres casos de esclerodermia.

(4) El factor antinuclear estaba presente en el suero $\omega$ del $65 \%$ de 183 enfermos con artritis reumatoide, $22 \% \infty$ de 49 casos de osteoartritis generalizada, $15 \%$ de $20 \%$ casos de osteoartritis secundaria, $15 \%$ de 33 casos de $\supset$ degeneración discal, $6 \%$ de 63 enfermos con otros disturbios reumáticos, $17 \%$ de 169 enfermos padeciendo otras varias enfermedades y $4 \%$ de 580 individuos aparentemente sanos.

(5) En la artritis reumatoide la incidencia del factor antinuclear fué más elevada entre los sujetos con signos de evolución mórbida (indicada por la presencia de $\vec{\oplus}$ anemia y elevada velocidad de sedimentación eritrơ citaria) y entre aquellos con seria afectación de la capack dad funcional. Un tipo severo de enfermedad ocurría cuando la presencia del factor antinuclear estaba asociada a una reacción positiva de aglutinación de los eritrocitos de carnero sensibilizados. Los enfermos en $\overline{\bar{O}}$ quienes ambas reacciones eran negativas están en todos los aspectos mejor que el resto del grupo.

(6) Se discute el posible significado de estos hallazgos. 